Note

\title{
CONVECTION REGIME BETWEEN CANOPY AND AIR IN A GREENHOUSE
}

\author{
Roberto Terumi Atarassi ${ }^{1}$; Marcos Vinicius Folegatti²*; René Porfírio Camponez do Brasil ${ }^{3}$ \\ ${ }^{1}$ R. Luiz de Camões, 2641, Apto. 74 - 13418-595 - Piracicaba, SP - Brasil. \\ ${ }^{2}$ USP/ESALQ - Depto. de Engenharia Rural, C.P. 09 - 13418-900 - Piracicaba, SP - Brasil. \\ ${ }^{3}$ USP/ESALQ - Programa de Pós-Graduação em Irrigação e Drenagem. \\ "Corresponding author <mvfolega@esalq.usp.br>
}

\begin{abstract}
The use of covering materials in protected environments modifies the air movement close to the crop canopy compared to external environment, which changes the heat and mass transfer between canopy and air. Several researches have been made in greenhouses to estimate mass and heat flux using dimensionless numbers to characterize the type of convection (forced, free or mixed). The knowledge of which one is dominant allows simplifications and specific approaches. The dominant convection regime between canopy and air was determined in a naturally ventilated greenhouse cropped with sweet pepper. Forced convection was predominant, representing more than $70 \%$ of the time. During daytime, an increase of mixed convection was observed. It is thus appropriated the use of models that include both forced and mixed convection in the studies of mass and heat exchanges in canopy - air interface.
\end{abstract}

Key words: heat flux, leaf, aerodynamic resistance

\section{REGIME DE CONVECÇÃO ENTRE DOSSEL E AR EM CASA DE VEGETAÇÃO}

\begin{abstract}
RESUMO: O uso de coberturas em ambientes protegidos altera a movimentação de ar próximo do dossel da cultura, comparado com o ambiente externo, modificando os processos de trocas de calor e massa entre dossel e ar. Muitos trabalhos realizados em casas de vegetação têm estimado os fluxos de calor latente e sensível com emprego de números adimensionais caracterizadores do tipo de regime convectivo. $\mathrm{O}$ conhecimento do tipo de regime predominante (forçado, livre ou misto) permite simplificações e abordagens mais específicas para estimativa destes fluxos. No presente trabalho, foi determinado o tipo de regime convectivo predominante entre dossel e ar, em uma casa de vegetação em arco, com ventilação natural com a cultura do pimentão amarelo. Na maior parte do tempo (>70\%) houve predominância da convecção forçada. Durante o dia, foi observado um pequeno aumento da convecção mista, sendo interessante para este período o uso de modelos que contemplem tanto a convecção mista quanto a forçada no estudo das trocas de calor e de massa entre dossel e ar.

Palavras-chave: fluxo de calor, folha, resistência aerodinâmica
\end{abstract}

\section{INTRODUCTION}

Covering of protected crops modifies environmental temperature and air movement as compared to external condition and, consequently, convective processes of mass and heat transfer between plant surface and air are affected. Many studies have used heat transfer theories based on the dimensionless numbers to characterize the type of convection regime (forced, free or mixed), to determine the aerodynamic resistance and estimate sensible and latent heat flux, with the last one representing the transpiration of plant (Stanghellini \& van Meurs, 1992; Papadakis et al., 1994; Zhang et al., 2002; Yang et al., 1990; Zolnier et al., 2001).
Occurrence of all types of convection regime has been registered, with predominance of forced and mixed. However, great part of the researches had used controlled greenhouses, equipped with ventilation systems, which lead to predominance of wind effect on heat exchanges. In Brazil, many commercial structures are not controlled due to the high investment cost, especially with less profitable crops like vegetables and some ornamental plants. Better characterization of these systems is thus necessary. The present work had aims to verify the type of predominant convection regime in the canopy, on sweet pepper crop, in a greenhouse with natural ventilation. 


\section{MATERIAL AND METHODS}

The study was carried out in Piracicaba, SP, Brazil (22 $42^{\prime} \mathrm{S}, 47^{\circ} 38^{\prime} \mathrm{W}$; altitude $520 \mathrm{~m}$ ), in a single span greenhouse, oriented east-west measuring $17.5 \mathrm{~m}$ $\times 6.4 \mathrm{~m}$, wall height $3.0 \mathrm{~m}$ and arc height $1.2 \mathrm{~m}$, covered with polyethylene film $0.15 \mathrm{~mm}$ thick. Lateral walls were constituted by $60 \%$ black shading screens and equipped with movable curtains, also made out of polyethylene film. Curtains were kept open, except in rainy days, adopting a similar management of local producers. Yellow sweet pepper plants, "Matador" variety, were transplanted in single rows, covered with silver plastic mulch, on August 19, 2004, at $0.5 \times 1.2$ $\mathrm{m}$ spacing, totalizing 155 plants. The crop was conducted in "V" form, with four stems per plant. Drip irrigation system was used to supply water and managed by tensiometers to keep soil moisture at a optimum level.

The following micrometeorological measurements were made inside the greenhouse (Figure 1): (a) wind speed near the canopy, by three-dimensional sonic anemometer (model CSAT3, Campbell Scientific Inc., offset $< \pm 0.04 \mathrm{~m} \mathrm{~s}^{-1}$, accuracy $< \pm 6 \%$ ); (b) canopy temperature, by copper-constantan thermocouples (AWG 40, with $0.08 \mathrm{~mm}$ diameter) installed at horizontal levels, $0.3 \mathrm{~m}$ from soil surface; three thermocouples were installed per level, in three leaves uniformly distributed, and attached to the back side of leaves with porous adhesive tape; (c) air temperature, measured by aspirated thermocouple psychrometers, installed every $0.30 \mathrm{~m}$ along of canopy height and with the first one located at $0.15 \mathrm{~m}$ from the soil surface.

Data were recorded by datalogger (Micrologger CR23X, Campbell Scientific Inc.), at 4 seconds sampling interval and record of averages every 30 minutes. Leaf area estimations were made with four plant samples, divided in level heights of $0.3 \mathrm{~m}$, the same stratification used for leaf and air temperature. The leaf area was estimated by measurements of length and width and application of the equation (1), determined previously by destructive method.

$$
\begin{aligned}
& L A=0.6397( \pm 0.0154) . L . W+0.2471( \pm 1.6445) \\
& \mathrm{R}^{2}=0.9945(\mathrm{SE}=2.58)
\end{aligned}
$$

where $L A, W$ and $L$ are the leaf area $\left(\mathrm{m}^{2}\right)$, width (m) and length $(\mathrm{m})$, respectively. Values in parenthesis refer to $95 \%$ confidence interval of estimation and SE is the standard error.

For analysis of the type of convection regime, measurements from periods when measurements of leaf area were made were used i.e., 09/28 to 10/03/2004, and from $10 / 09$ to $10 / 13 / 2004$, (Table 1 ). The reduction of leaf area between 09/30 and 10/08 was due to conduction pruning made in this period. Leaf area was assumed as constant during each period of leaf area measurements, since time was very short to observe significant growth.

The average canopy temperature was obtained by weighed mean of leaf temperature per leaf area in each layer, represented in equation (2).

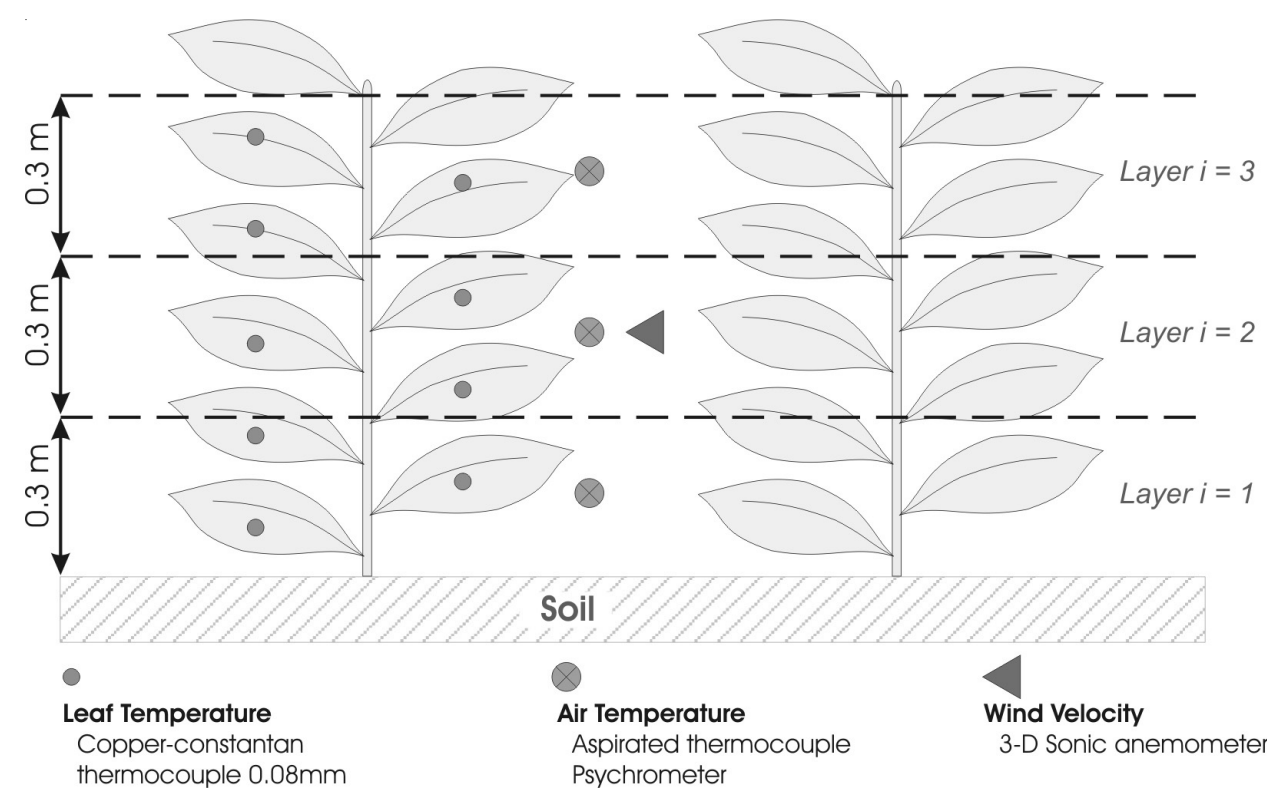

Figure 1 - Schematic representation of position of the used sensors. 
Table 1 - Leaf area measurements per plant, average area of one leaf $(\overline{L A})$, leaf area index (LAI) and characteristic length of the leaf $(l)(\mathrm{DAT}=$ Days after transplant; $\mathrm{CV}=$ coefficient of variation $)$.

\begin{tabular}{lcccccc}
\hline & Day & DAT & Leaf area/plant & LA & LAI & $l$ \\
\hline \multirow{2}{*}{ Average } & & & $----------\mathrm{m}^{2}----------$ & & $\mathrm{m}$ \\
& $09 / 30 / 2004$ & 42 & 0.43690 & 0.004141 & 2.006 & 0.0628 \\
\hline Standard deviation & $10 / 08 / 2004$ & 50 & 0.32564 & 0.006232 & 1.361 & 0.0721 \\
& $09 / 30 / 2004$ & 42 & 0.10737 & 0.003941 & 0.065 & \\
\hline CV (\%) & $10 / 08 / 2004$ & 50 & 0.05382 & 0.005198 & 0.081 & \\
& $09 / 30 / 2004$ & 42 & 24.58 & 95.16 & 10.72 & \\
\hline
\end{tabular}

$$
T_{L}=\frac{\sum_{i} L A P i \cdot T_{L} i}{L A P}
$$

where $T_{L}$ is de average temperature of leaves $(\mathrm{K}), L A P i$ is the leaf area per plant in layer $i$ (see Figure 1), $T_{L} i$ is the average leaf temperature in layer $i$ and $L A P$ is the total leaf area per plant.

The average of measurements supplied by aspirated psychrometers was used to determine air temperature. As the processes of energy exchanges are more significant during the daytime, by transpiration and radiation exchanges, separate analyses for daytime and nighttime were processed. Determination of the type of dominant convection was made comparing the magnitudes of driving forces that command the free and forced convection by application of equation (3) (Incropera \& DeWitt, 1996; Zolnier et al., 2001):

$$
G r / \operatorname{Re}^{2}=\frac{g \cdot \beta \cdot l \cdot\left|T_{L}-T_{a}\right|}{u^{2}}
$$

where $G r$ is the Grashof number (dimensionless), Re is the Reynolds number (dimensionless), $\beta$ is the gravity acceleration $\left(\mathrm{m} \mathrm{s}^{-2}\right), b$ is the volumetric thermal expansion coefficient $\left(\mathrm{K}^{-1}\right), l$ is the characteristic length (m), $\left|T_{L}-T_{a}\right|$ is the absolute value of the temperature difference between surface and fluid in free stream $(\mathrm{K})$, and $u$ is the free stream velocity of the fluid $\left(\mathrm{m} \mathrm{s}^{-1}\right)$. The research focuses on application of heat transfer theory and details about equations, and terms can be found in Incropera \& DeWitt (1996) and Duffie \& Beckman (1991).

When the convection is forced $(\mathrm{Gr} / \mathrm{Re} 2<<1)$ or free $(\mathrm{Gr} / \mathrm{Re} 2>>1)$, the aerodynamic resistance $(\mathrm{ra})$ can be calculated by classical equations of heat transfer, simplifying its determination (Zolnier et al., 2001). Under mixed conditions $(\mathrm{Gr} / \operatorname{Re} 2 \cong 1)$, the effect of the wind speed and the difference of canopy-air temperature must be combined. One specific classification given by Gates (1980), considers the free convection if $\mathrm{Gr} / \mathrm{Re} 2>16$ and forced convection if $\mathrm{Gr} / \mathrm{Re} 2<0.1$. The values of $3.42 \times 10^{-3} \mathrm{~K}^{-1}$ for thermal expansion coefficient of air at $20^{\circ} \mathrm{C}$ and $g 9.81 \mathrm{~m} \mathrm{~s}^{-2}$ were used in the evaluation. The equations were applied to the averages of 30 minutes of collected data. The characteristic length of the leaf was calculated by the expression (Boulard et al., 1989):

$$
l=\sqrt{\overline{L A}}
$$

where $\overline{L A}$ is the average area of one leaf $\left(\mathrm{m}^{2}\right)$.

\section{RESULTS AND DISCUSSION}

Along a 24-h period, in excess of $90 \%$ of the time, the $\mathrm{Gr} / \mathrm{Re}^{2}$ ratio assumed values lower than 0.25 , indicating predominance of forced convection, mainly during the night, where $90 \%$ of the time $\mathrm{Gr} / \mathrm{Re}^{2}$ were lower than 0.16 (Table 2 and Figure 2). These results can be explained by reduction in the average value of $\left|\mathrm{T}_{\mathrm{L}}-\mathrm{T}_{\mathrm{a}}\right|$ during this period, reducing the action of the thermal convection in the exchange processes. During daytime, the solar radiation promotes the heating of the canopy, increasing the difference of temperature between leaf and air, leading to an amplification of the thermal convection. Even though values of $\mathrm{Gr} / \mathrm{Re}^{2}$ are lower than one most of the time, these are relatively close to the mixed regime, especially during the daytime. Appling Gates (1980) classification (Table 3), only the forced and mixed convection was observed during the period of study, with increase of the mixed during the daytime (29.0\% of the time) compared with the nighttime ( $17.7 \%$ of the time).

Mass and heat exchanges in greenhouses are usually governed by mixed convection (Stanghellini, 1993), suggesting the equation (5) (Stanghellini \& van Meurs, 1992) for calculation of the aerodynamic resistance. Working with artificial leaves inside a greenhouse (Bailey \& Meneses, 1995), also observed the predominance of mixed convection in these conditions. 
Table 2 - Average and maximum values and 50\% and 90\% cumulated frequency of wind velocity (u), air temperature (Ta), leaf temperature $\left(\mathrm{T}_{\mathrm{L}}\right),\left(\mathrm{T}_{\mathrm{L}}-\mathrm{Ta}\right),\left|\mathrm{T}_{\mathrm{L}}-\mathrm{Ta}\right|$ and relation $\mathrm{Gr} / \mathrm{Re}^{2}$.

\begin{tabular}{|c|c|c|c|c|c|c|c|}
\hline \multirow[t]{2}{*}{ Period } & & $\mathrm{u}$ & $\mathrm{Ta}$ & $\mathrm{T}_{\mathrm{L}}$ & $\mathrm{T}_{\mathrm{L}}-\mathrm{Ta}$ & $\left|\mathrm{T}_{\mathrm{L}}-\mathrm{Ta}\right|$ & $\mathrm{Gr} / \mathrm{Re}^{2}$ \\
\hline & & $\mathrm{m} \mathrm{s}^{-1}$ & 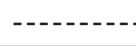 & -.-- & - & - & \\
\hline \multirow[t]{4}{*}{ Nighttime } & Average & 0.115 & 19.55 & 19.42 & -0.122 & 0.142 & 0.068 \\
\hline & $50 \%$ frequency & 0.091 & & & & & $<0.030$ \\
\hline & $90 \%$ frequency & 0.219 & & & & & $<0.160$ \\
\hline & Maximum & 0.416 & 30.74 & 29.52 & 0.246 & 1.219 & 1.346 \\
\hline \multirow[t]{4}{*}{ Daytime } & Average & 0.184 & 26.32 & 25.47 & -0.846 & 0.952 & 0.163 \\
\hline & $50 \%$ frequency & 0.163 & & & & & $<0.050$ \\
\hline & $90 \%$ frequency & 0.365 & & & & & $<0.393$ \\
\hline & Maximum & 0.613 & 38.74 & 35.43 & 1.894 & 6.638 & 3.290 \\
\hline \multirow[t]{4}{*}{ Whole period } & Average & 0.145 & 22.52 & 22.08 & -0.440 & 0.526 & 0.110 \\
\hline & $50 \%$ frequency & 0.095 & & & & & $<0.038$ \\
\hline & $90 \%$ frequency & 0.307 & & & & & $<0.250$ \\
\hline & Maximum & 0.613 & 38.74 & 35.43 & 1.894 & 6.638 & 3.290 \\
\hline
\end{tabular}

Table 3 - Frequency of forced $\left(\mathrm{Gr} / \mathrm{Re}^{2}<0.1\right)$ and mixed $\left(0.1<\mathrm{Gr} / \mathrm{Re}^{2}<16\right)$ convection by Gates $(1980)$ classification.

\begin{tabular}{lcc}
\hline Period & Convection type & Frequency (\%) \\
\hline Nighttime & Forced & 82.3 \\
& Mixed & 17.7 \\
\hline Daytime & Forced & 71.0 \\
& Mixed & 29.0 \\
\hline Whole period & Forced & 77.0 \\
& Mixed & 23.0 \\
\hline
\end{tabular}

These reports differ from the results observed in the present work, where the forced convection was more frequent. The fact of the authors had carried out their measurements in greenhouse with heating system and forced ventilation, which increases air movement, would lead to opposite results, amplifying the forced convection. Therefore, particular characteristics of the greenhouse, local climate, and crop, may influence decisively in the type of convective, a thus emphasizing the need for local determination.

$$
r_{a}=\frac{1174 \cdot l^{0.5}}{\left(l\left|T_{L}-T_{a}\right|+207 \cdot u^{2}\right)^{0.25}}
$$

Zolnier et al. (2001) found average values of 0.0067 for $\mathrm{Gr} / \mathrm{Re}^{2}$ ratio, indicating that forced convection was dominant in the exchanges of sensible heat. The aerodynamic resistance of canopy $\left(r_{c}\right)$ was calculated by equation (6), suitable for this condition. This result was expected since the study was carried out in environmental chambers with forced ventilation. Even working in different conditions, in comparison to the present research, the aerodynamic resistance may be calculated by the same method, due to the similar predominance of the forced convection. Boulard \& Wang (2000) obtained good results assuming only the exchanges by forced convection in the development of a model of transpiration for a greenhouse with heating, ventilation and lateral vent opening. The aerodynamic resistance of a leaf was calculated with the equation (7), in accordance with results obtained in the present work.

$$
\begin{aligned}
& r_{c}=\frac{\left(\frac{l}{\alpha \cdot u}\right)^{1 / 2} \cdot \operatorname{Pr}^{1 / 6}}{1.328 \cdot L A I} \\
& r_{a}=220 \cdot \frac{l^{0.2}}{u^{0.8}}
\end{aligned}
$$

where $\alpha$ is the thermal diffusivity $\left(\mathrm{m}^{2} \mathrm{~s}^{-1}\right), P r$ is the Prandtl number (dimensionless) and $L A I$ is the leaf area index.

The differences among results reported in literature and for the present experiment emphasize the importance of local measurements for use and development of heat exchanges models, especially in Brazil, which has large climatic variation throughout its territory.

Cumulative frequency curves of $\mathrm{Gr} / \mathrm{Re}^{2}$ presented in Figure 2 allow a better visualization of the predominance of forced convection and occurrence, at some moments, mainly during the daytime, of mixed convection. As the processes of energy exchanges are 

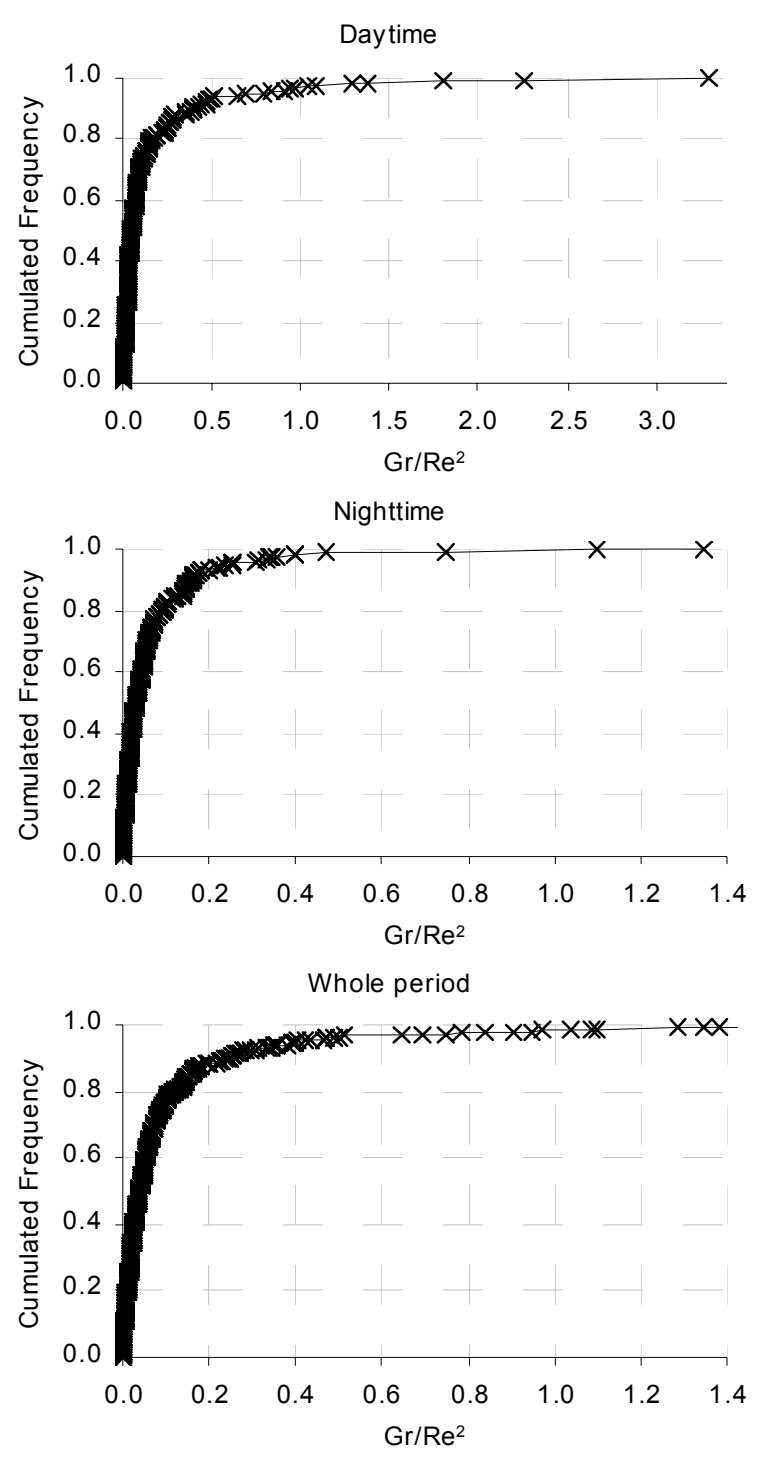

Figure 2 - Cumulated frequency of $\mathrm{Gr} / \mathrm{Re}^{2}$ for daytime, nighttime and whole period.

more pronounced during the daytime, it is recommended that estimation of sensible and latent heat exchange take in account the mixed and forced convection when precise estimations are desired. Although in low proportion, the mixed convection is not negligible. However, under conditions similar to those of the present work, even estimations considering only the forced convection would represent adequately great part of convection exchanges, as assumed by Boulard \& Wang (2000) and Zolnier et al. (2001).

\section{ACKNOWLEDGMENTS}

We wish to thank to The State of São Paulo Research Foundation (FAPESP) for granting of the financial support to this research.

\section{REFERENCES}

BAILEY, B.J.; MENESES, J.F. Modelling leaf convective heat transfer. Acta Horticulturae, n.399, p.191-198, 1995.

BOULARD, T.; WANG, S. Greenhouse crop transpiration simulation from external climate conditions. Agricultural and Forest Meteorology, v.100, p.25-34, 2000.

BOULARD, T.; BAILlE, A.; LAGIER, J.; MERMIER, M.; VANDERSCHMITT, E. Water vapor transfer in a plastic house equipped with a dehumidification heat pump. Journal of Agricultural Engineering Research, v.44, p.191-204, 1989.

DUFIE, J.A.; BECKMAN, W.A. Solar engineering of thermal processes. 2.ed. New York: Wiley-Interscience, 1991. 919p.

GATES, D.M. Biophysical ecology. New York: Springer-Verlag, 1980. $611 \mathrm{p}$.

INCROPERA, F.P.; DEWITT, D.P. Fundamentals of heat and mass transfer. 4.ed. New York: John Wiley \& Sons, 1996. 886p.

PAPADAKIS, G.; FRANGOUDAKIS, A.; KYRITSIS, S. Experimental investigation and modelling of heat and mass transfer between a tomato crop and the greenhouse environment. Journal of Agricultural Engineering Research, v.57, p.217-227, 1994.

STANGHELLINI, C. Mixed convection above greenhouse crop canopies. Agricultural and Forest Meteorology, v.66, p.111-117, 1993.

STANGHELLINI, C.; VAN MEURS, W.T.M. Environmental control of greenhouse crop transpiration. Journal of Agricultural Engineering Research, v.51, p.297-311, 1992.

YANG, X.; SHORT, T.H.; FOX, R.D.; BAUERLE, W.L. Dynamic modeling of the microclimate of a greenhouse cucumber row-crop part I. Theoretical model. Transactions of the ASAE, v.33, p.1701$1709,1990$.

ZHANG, Y.; JEWETT, T.L.; SHIPP, J.L. A dynamic model to estimate in-canopy and leaf-surface microclimate of greenhouse cucumber crops. Transactions of the ASAE, v.45, p.179-192, 2002.

ZOLNIER, S.; GATES, R.S.; GENEVE, R.L.; BUXTON, J.W. Surface diffusive resistances of rooted poinsettia cuttings under controlledenvironment conditions. Transactions of the ASAE, v.44, p.17791787, 2001.

Received April 29, 2005

Accepted December 28, 2005 